\title{
The Development of Animation Video Based on Scientific Literacy as Instructional Media Science for Upper Grade Primary Schools
}

\author{
Mey Prihandani Wulandari, Amalia Nurul Azizah, Hesti Nurlaeli \\ STKIP Darussalam Cilacap \\ meyprihandani@stkipdarussalam.ac.id
}

\section{Article History}

accepted 24/09/2019

approved 01/10/2019

published 01/12/2019

\begin{abstract}
The aims of this study are (1) Produce an animation video based on scientific literacy as instructional media science, (2) Knowing the quality of animation video based on scientific literacy as instructional media science. This study was categorized as Research and Development $(R \& D)$. The subjects in this study is some experts (media, languages, and material), teachers and grade IV students. The results of this study are (1) The animation video based on scientific literacy produced is instructional science media for grade IV students on the "Selalu Berhemat Energi", (2) The quality of this media included in "Very Good" category and didn't have difficulties when using it according to assessment of some experts (media, languages, and material), teachers and grade IV students. The implication is an alternative to improve scientific literacy through improving critical thinking, creative thinking, and interest in reading sains and most importantly thing is the discourse "Energy Saving"
\end{abstract}

Keywords: Animation Video; Scientific Literacy; Research and Development (R\&D); Science; Upper Grade Primary Schools

\begin{abstract}
Abstrak
Penelitian ini bertujuan: (1) Mengembangkan video animasi IPA SD berbasis literasi sains, (2) Mengetahui kualitas video animasi IPA SD berbasis literasi sains. Jenis penelitian yang dilakukan berupa Riset dan Pengembangan (R\&D). Sebjek penelitian ini meliputi beberapa ahli (media, bahasa, dan materi), guru dan siswa Kelas IV. Hasil penelitian ini menunjukkan (1) Media video animasi IPA SD berbasis literasi sains yang dihasilkan merupakan media pembelajaran IPA untuk kelas IV SD pada kurikulum 2013 dengan tema "Selalu Berhemat Energi", (2) Kualitas media video animasi IPA SD berbasis literasi sains berada pada kategori "Sangat Baik" dan pengguna media tidak mengalami kesulitan saat menggunakannya menurut penilaian beberapa ahli (media, bahasa, dan materi), guru dan siswa Kelas IV. Implikasi penelitian ini adalah alternatif media pembelajaran dalam meningkatkan cara berpikir kritis dan kreatif serta meningkatkan minat membaca materi pelajaran IPA sehingga dapat meningkatkan literasi sains siswa dan yang terpenting didalam materi tersebut terdapat wacana "Hemat Energi".
\end{abstract}

Kata kunci: Media video animasi, Literasi sains, Ilmu Pengetahuan Alam, Penelitian dan Pengembangan (R\&D), Sekolah Dasar Kelas Atas

Social, Humanities, and Education Studies (SHEs): Conference Series https://jurnal.uns.ac.id/shes 


\section{PENDAHULUAN}

Pada jenjang pendidikan Sekolah Dasar, salah satu mata pelajaran yang dipelajari adalah IPA yang mempunyai peran penting dalam mensejahterakan manusia, sehingga penting dipelajari pada jenjang pendidikan sedini mungkin. Samatowa (2016) menyatakan bahwa IPA merupakan segala sesuatu yang berkaitan dengan alam semesta dan isinya yang dapat dipelajari secara objektif dan rasional. Sedangkan menurut Susanto (2016), IPA merupakan usaha dalam mempelajari alam semesta yang dilakukan oleh manusia melalui kegiatan penelitian dengan menggunakan metode ilmiah. Dari beberapa pendapat para ahli diatas, dapat disimpulkan bahwa pembelajaran IPA secara tidak langsung memberikan motivasi kepada siswa untuk meningkatkan rasa ingin tahu dalam diri siswa itu sendiri terhadap kejadian-kejadian di alam semesta, yang kemudian siswa secara tidak langsung akan mengembangkan kemampuan bertanya, mengembangkan kemampuan mencari jawaban penyelesaian dari bukti yang diperoleh, serta mengembangkan cara berpikir ilmiah. Dan untuk mencapai itu semua, salah satu cara yang dapat dilakukan adalah dengan penerapan literasi sains dalam proses pembelajarannya.

Menurut OECD (Organization for Economic Cooperation and Development) dalam kemdikbud (2017) literasi sains adalah kemampuan siswa dalam mencari jawaban penyelesaian dari bukti atau fakta yang diperoleh dengan cara menjelaskan fenomena ilmiah yang terjadi. Sehingga siswa dapat melek sains, menjadikan siswa sadar bahwa IPTEK mempunyai kontribusi besar terhadap lingkungan, serta menjadikan siswa memiliki kepedulian terhadap lingkungan yang ada disekitar dalam kehidupan sehari-hari. Allison and Goldston (2018) menyebutkan bahwa siswa yang melek sains akan dapat mentransfer pengetahuan dan ketrampilan sains yang dimiliki untuk diaplikasikan dalam kehidupan sehari-hari mereka. Rakhmawan, dkk (2015) menjelaskan bahwa dalam pembelajaran IPA, siswa yang mempunyai kemampuan literasi sains yang baik akan termotivasi dalam membangun sendiri kebermaknaan pengetahuan secara optimal dari apa yang telah dipelajari. Dari penjelasan beberapa ahli di atas, dapat ditarik kesimpulan bahwa literasi sains sangatlah penting untuk diterapkan dalam kegiatan pembelajaran di kelas, sehingga siswa akan terlatih terbiasa dalam memecahkan permasalahan yang dihadapinya dalam kehidupan sehari-hari dengan cara berpikir kritis dan kreatif, siswa dapat beradaptasi untuk menyesuaikan diri lingkungan dengan cara terampil berkomunikasi dengan orang lain, dan siswa dapat membuka diri untuk dapat berkolaborasi dengan orang lain untuk mengembangkan ide-ide yang nantinya dapat berkontribusi terhadap lingkungan sosial masyarakat sekitar.

Literasi sains siswa di Indonesia menurut hasil penelitian PISA (Programme for International Student Assesment) dengan penyelenggaranya adalah OECD berada pada kategori masih rendah. Rafidah (2017) menyebutkan bahwa pada tahun 2012, perolehan rata-rata skor sebesar 382 dan menempati peringkat ke 64 (dari 65 negara) dan tahun 2015 diperoleh rata-rata skor 403 dengan menempati peringkat ke 64 (dari 72 negara). Dengan kondisi seperti ini, perlu adanya perbaikan cara pembelajaran dengan mengembangkan media pembelajaran yang disesuaikan dengan perkembangan zaman dan juga harus mendukung literasi sains sehingga siswa memiliki pengetahuan yang lebih bermakna.

Salah satu media pembelajaran yang dapat dikembangkan adalah video animasi yang memadukan audio dan visual di dalamnya. Azhar (2013) menyatakan bahwa dalam proses pembelajaran, media video animasi memiliki peran yang penting diantaranya dapat meningkatkan pemahaman, memperkuat ingatan, menumbuhkan motivasi untuk mengaitkan materi dengan kehidupan sehari-hari. Sedangkan menurut Munir (2015) menjelaskan bahwa video animasi merupakan proses menciptakan suatu gerakan sebuah objek dengan cara berpindah tempat, merubah warna atau merubah bentuk objek tersebut. Dari penjelasan para ahli diatas, penerapan media video 
animasi sangatlah layak diterapkan dalam pembelajaran untuk mencapai tujuan pembelajaran yang akan dicapai, agar supaya media video animasi menjadi efektif untuk diterapkan, maka sebaiknya di dalam media tersebut dirancang agar memungkinkan siswa dapat melakukan interaksi terhadap visual yang dibuat dan dapat mendukung literasi sains, sehingga proses pertukaran informasi dapat terjadi dan siswa memiliki pengetahuan yang lebih bermakna. Selain itu, menurut hasil penelitian yang dilakukan Riwanto (2018) menjelaskan bahwa untuk menyampaikan materi IPA agar siswa dapat menguasai konsep materi yang dipelajari salah satunya dengan menggunakan media pembelajaran yang didalamnya terdapat kegiatan interaktif untuk meningkatkan keterampilan dalam menganalisis permasalahan berupa sebab akibat dari fenomena alam yang terjadi ataupun mencari solusi atas permasalahan yang ditimbulkan oleh fenomena alam tersebut. Dari hasil penelitian tersebut, dapat ditarik kesimpulan bahwa penerapan media yang terdapat kegiatan interaktif di dalamnya juga dapat meningkatkan literasi sains siswa.

Untuk menyelesaikan permasalahan di atas, peneliti akan mengembangkan media video animasi IPA berbasis literasi sains untuk kelas atas SD pada kurikulum 2013. Menurut Piaget dalam Sulistyaningsih (2015) menyebutkan bahwa karakteristik siswa kelas IV dalam cara berfikir masih bersifat konkrit dan belum mampu mempelajari sesuatu yang abstrak, sehingga perlu adanya alat bantu visual untuk mempermudah pemahaman siswa. Tema yang dipilih adalah Selalu Berhemat Energi untuk siswa kelas IV SD dengan alasan peneliti tertarik dengan wacana "Hemat Energi" dan karakter materi didalamnya berupa pengetahuan. Karakter ini mendukung penggunaan media video animasi sehingga siswa mau membaca. Dalam tema Selalu Berhemat Energi berisi tentang materi sumber energi, manfaat energi, dan energi alternatif. Dalam penelitian ini, di dalam media yang akan dikembangkan juga akan dirancang kegiatan interaktif siswa berupa menganalisis pemanfaatan sumber daya alam tertentu sehingga dapat meningkatkan ketrampilan berfikir kritis dan kreatif siswa dalam menganalisis masalah dan mencari solusi bersama dalam rangka meningkatkan ketrampilan berkomunikasi dan berkolaborasi dengan orang lain.

Rumusan penelitian berdasarkan latar belakang di atas meliputi: (1) Bagaimanakah pengembangan media pembelajaran video animasi IPA SD berbasis literasi sains pada tema Selalu Berhemat Energi? (2) Bagaimanakah kualitas media pembelajaran video animasi IPA SD berbasis literasi sains pada tema Selalu Berhemat Energi menurut penilaian berbagai ahli (media, bahasa, dan materi), guru dan siswa Kelas IV?

Tujuan penelitian berdasarkan rumusan masalah diatas adalah (1) Mengembangkan media video animasi IPA SD berbasis literasi sains pada tema Selalu Berhemat Energi, (2) Mengetahui kualitas media pembelajaran video animasi IPA SD berbasis literasi sains pada tema Selalu Berhemat Energi menurut penilaian berbagai ahli (media, bahasa, dan materi), guru dan siswa Kelas IV?.

Pengembangan media video animasi berbasis literasi sains diharapkan dapat berperan dalam mengembangkan proses pembelajaran dan bermanfaat kepada berbagai pihak, diantaranya: (1) Bagi siswa: mendapatkan alternatif media pembelajaran dalam meningkatkan cara berpikir kritis dan kreatif serta meningkatkan minat membaca materi pelajaran IPA sehingga dapat meningkatkan literasi sains siswa. (2) Bagi guru: terbantu dalam menarik perhatian siswa dan termotivasi dalam mengembangkan sendiri media pembelajaran yang sesuai dengan kebutuhan siswanya masing-masing dengan memperhatikan potensi daerah sekolah. (3) Bagi Sekolah: memberikan sumbangsih media pembelajaran yang dapat meningkatkan kualitas proses dan hasil pembelajaran di sekolah. 


\section{METODE}

Jenis dan prosedur penelitian yang digunakan dalam penelitian ini adalah berupa penelitian riset dan pengembangan (Research and Development) yang mengarah pada model Brog and Gall. Sebjek penelitian ini meliputi beberapa ahli (media, bahasa, dan materi), guru dan siswa Kelas IV. Riset dan Pengembangan diawali dengan melakukan observasi kebutuhan isi media pembelajaran video animasi IPA SD berbasis literasi sains, dilanjutkan dengan membuat draft media yang kemudian dilanjutkan dengan produksi media pembelajaran, selanjutnya dilakukan validasi ahli dan uji coba penggunaan media pembelajaran, jika terdapat kekurangan maka dilakukan revisi. Lokasi penelitian adalah Sekolah Dasar baik Negeri maupun Swasta yang berada di Kabupaten Cilacap, Provinsi Jawa Tengah. Metode pengumpulan data yang digunakan meliputi metode wawancara, pengisian lembar evaluasi/ angket check list dan dokumentasi. Data yang diperoleh adalah berupa data penilaian kualitas media video animasi yang berasal dari hasil check list yang diisi oleh beberapa ahli (media, bahasa, dan materi), guru dan siswa Kelas IV. Data kuantitatif yang diperoleh kemudian diolah dengan perhitungan rata-rata skor untuk masing-masing aspek penilaian dalam menentukan kualitas media pembelajaran secara keseluruhan dan tahap selanjutnya mengubah rata-rata skor masing-masing aspek penilaian tersebut menjadi nilai kualitatif dengan melihat kriteria katergori penilaian ideal yang dapat dilihat pada Tabel 2 (Sukarjo dalam Fahmi, 2017).

Tabel 1. Aturan pemberian skor angket check list

\begin{tabular}{ccc}
\hline No. & Keterangan & Skor \\
\hline 1 & Sangat relevan/ sangat baik & 5 \\
2 & Relevan/ baik & 4 \\
3 & Cukup relevan/ cukup baik & 3 \\
4 & Kurang relevan/ kurang baik & 2 \\
5 & Tidak relevan/ tidak baik & 1 \\
\hline
\end{tabular}

Tabel 2. Konversi Nilai Kualitatif Sesuai dengan Kriteria Katergori Penilaian Ideal

\begin{tabular}{ccc}
\hline No. & Rentang Skor & Kriteria \\
\hline 1 & $\mathrm{Mi}+1,8 \mathrm{Sbi}<\mathrm{X}$ & Sangat Baik \\
2 & $\mathrm{Mi}+0,6 \mathrm{Sbi}<\mathrm{X} \leq \mathrm{Mi}+1,8 \mathrm{Sbi}$ & Baik \\
3 & $\mathrm{Mi}-0,6 \mathrm{Sbi}<\mathrm{X} \leq \mathrm{Mi}+0,6 \mathrm{Sbi}$ & Cukup \\
4 & $\mathrm{Mi}-1,8 \mathrm{Sbi}<\mathrm{X} \leq \mathrm{Mi}-0,6 \mathrm{Sbi}$ & Kurang \\
5 & $\mathrm{X} \leq \mathrm{Mi}-1,8 \mathrm{Sbi}$ & Sangat Kurang \\
\hline
\end{tabular}

\section{HASIL DAN PEMBAHASAN}

Penelitian R\&D merupakan suatu penelitian yang hasil akhirnya dapat berupa produk baru ataupun modifikasi produk yang telah dibuat oleh peneliti lain (Irfandi, 2015). Adapun hasil pengembangan yang merupakan luaran wajib dari penelitian ini adalah purwarupa/prototipe dalam bentuk produk baru berupa media video animasi IPA SD berbasis literasi sains yang merupakan media pembelajaran IPA untuk kelas IV SD pada kurikulum 2013 dengan tema Selalu Berhemat Energi dimana karakter materi didalamnya secara keseluruhan berisi tentang pengetahuan sehingga media ini dapat menjadi alternatif untuk meningkatkan literasi sains siswa dan yang terpenting didalam materi tersebut terdapat wacana "Hemat Energi" sehingga mampu membantu pemerintah dalam hal mensosialisasikan program hemat energi terhadap siswa.

Model R\&D yang dilakukan mengarah pada model Brog and Gall yang didalamnya terdapat 10 tahapan yang harus dilakukan. 10 tahapan tersebut meliputi: (1) penelitian dan pengumpulan informasi: melakukan observasi kebutuhan isi media pembelajaran video animasi IPA SD berbasis literasi sains yang dilakukan dengan cara studi lapangan, studi pustaka, dan pengumpulan informasi (berupa observasi 
pendataan alat penunjang media LCD pada SD Negeri dan Swasta di Kecamatan Karangpucung, Majenang dan Sidareja); (2) perencanaan: membuat bagan perencanaan media dan kerangka isi utama media; (3) pengembangan bentuk produk pendahuluan: terdapat empat langkah, yaitu pra penulisan, penulisan draft, penyuntingan (dilakukan validasi ahli terhadap media pembelajaran), dan revisi (terkait dengan timing animasi gambar); (4) uji coba lapangan awal: yang terlibat hanya 1 guru dan 3 siswa di SD Negeri Surusunda 1 Karangpucung; (5) revisi terhadap produk awal: tidak dilakukan, karena masukan yang diberikan baik guru maupun siswa bukan berkaitan dengan produk, tetapi lebih meminta pengembangan media pembelajaran untuk tema-tema yang lainnya; (6) uji coba utama: yang terlibat adalah 1 guru dan siswa 1 kelas di SD Negeri Ciporos 3 Karangpucung; (7) revisi produk operasional: tidak dilakukan, karena baik guru dan siswa tidak memberikan masukan terhadap media melainkan penilaian positif terhadap media ini; (8) uji coba operasional: yang terlibat adalah 2 sekolah yaitu satu sekolah negeri (SD Negeri Tayem 1 Karangpucung) dan satu sekolah swasta (MI Al-Hidayah Surusunda); (9) revisi produk akhir: tidak dilakukan, karena baik guru dan siswa tidak memberi masukan dan tidak mengalami kendala pada saat penggunaannya; (10) deseminasi dan implementasi: mendeseminasikan media video animasi IPA SD berbasis literasi sains ke 50 Sekolah Dasar baik Negeri maupun Swasta di Kabupaten Cilacap.

Adapun rincian data hasil penilaian dari beberapa ahli (media, bahasa, dan materi), guru, dan siswa kelas IV terhadap kualitas media pembelajaran adalah sebagai berikut:

a. Hasil penilaian Ahli Media

Tabel 3| Rata-rata Skor dan Kriteria Penilaian Ahli Media

\begin{tabular}{clcc}
\hline No. & \multicolumn{1}{c}{ Aspek penilaian } & $\begin{array}{c}\text { Rata-Rata } \\
\text { Skor }\end{array}$ & Kriteria \\
\hline 1 & Tampuilan Umum & 23 & Sangat Baik \\
2 & Tampilan Khusus & 22 & Sangat Baik \\
3 & Penyajian media video animasi & 18 & Sangat Baik \\
& berbasis literasi sains & & \\
\hline
\end{tabular}

b. Hasil penilaian Ahli Bahasa

Tabel 4. Rata-rata Skor dan Kriteria Penilaian Ahli Bahasa

\begin{tabular}{clcc}
\hline No. & \multicolumn{1}{c}{ Aspek penilaian } & $\begin{array}{c}\text { Rata-Rata } \\
\text { Skor }\end{array}$ & Kriteria \\
\hline 1 & Ketepatan kalimat & 15 & Sangat Baik \\
2 & Gaya bahasa & 14 & Sangat Baik \\
3 & Tata tulis & 18 & Sangat Baik \\
\hline
\end{tabular}

c. Hasil penilaian Ahli Materi

Tabel 5. Rata-rata Skor dan Kriteria Penilaian Ahli Media

\begin{tabular}{clcc}
\hline No. & \multicolumn{1}{c}{ Aspek penilaian } & $\begin{array}{c}\text { Rata-Rata } \\
\text { Skor }\end{array}$ & Kriteria \\
\hline 1 & Relevansi & 27 & Sangat Baik \\
2 & Keakuratan & 19 & Sangat Baik \\
3 & Kelengkapan sajian & 5 & Sangat Baik \\
4 & Konsep dasar materi & 15 & Sangat Baik \\
5 & Kesesuaian sajian dengan tuntutan & 14 & Sangat Baik \\
\hline
\end{tabular}


d. Hasil penilaian Guru

Tabel 6. Rata-rata Skor dan Kriteria Penilaian Guru

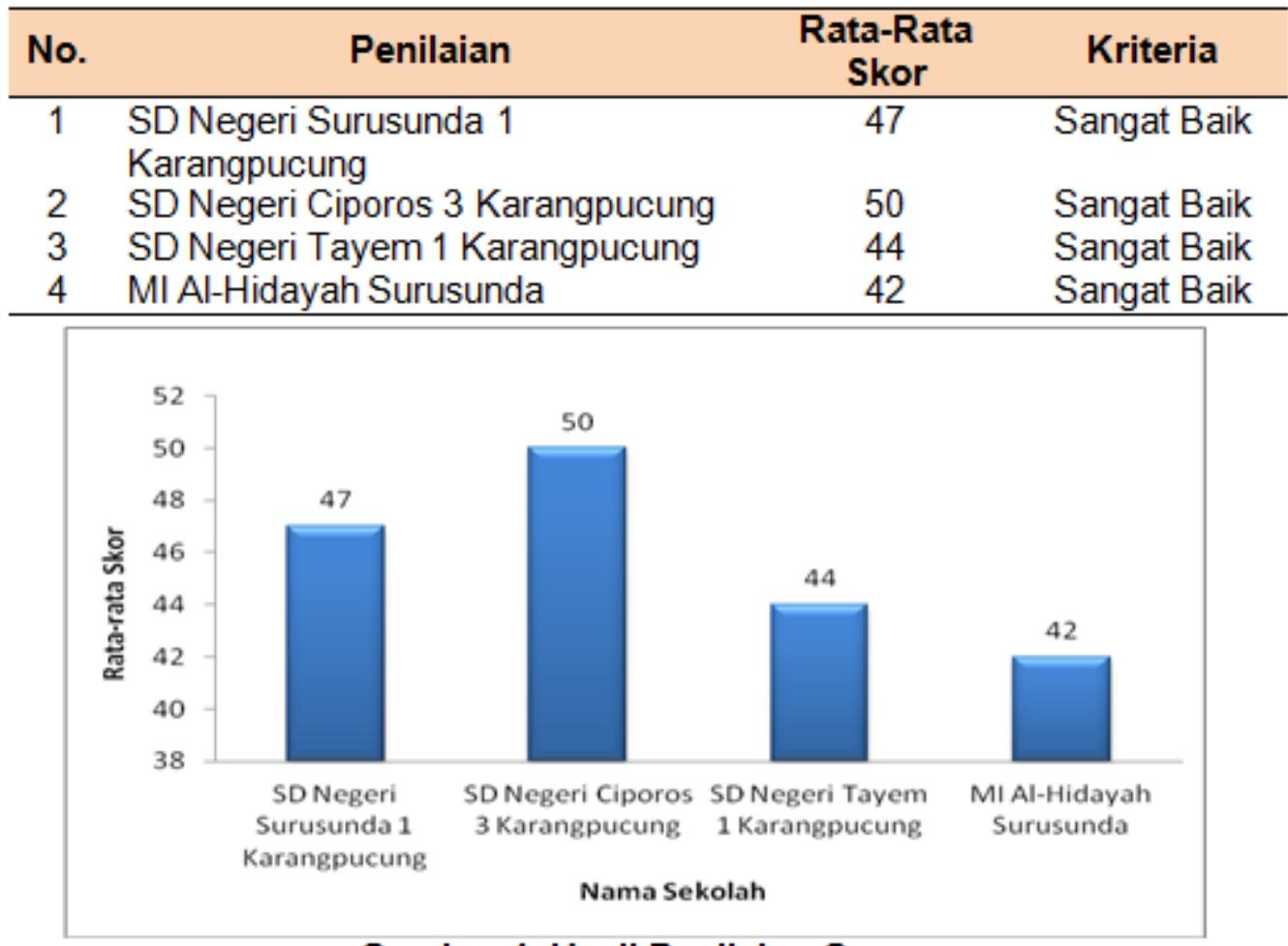

\section{Gambar 1. Hasil Penilaian Guru}

e. Hasil penilaian Siswa

Tabel 7. Rata-rata Skor dan Kriteria Penilaian Siswa

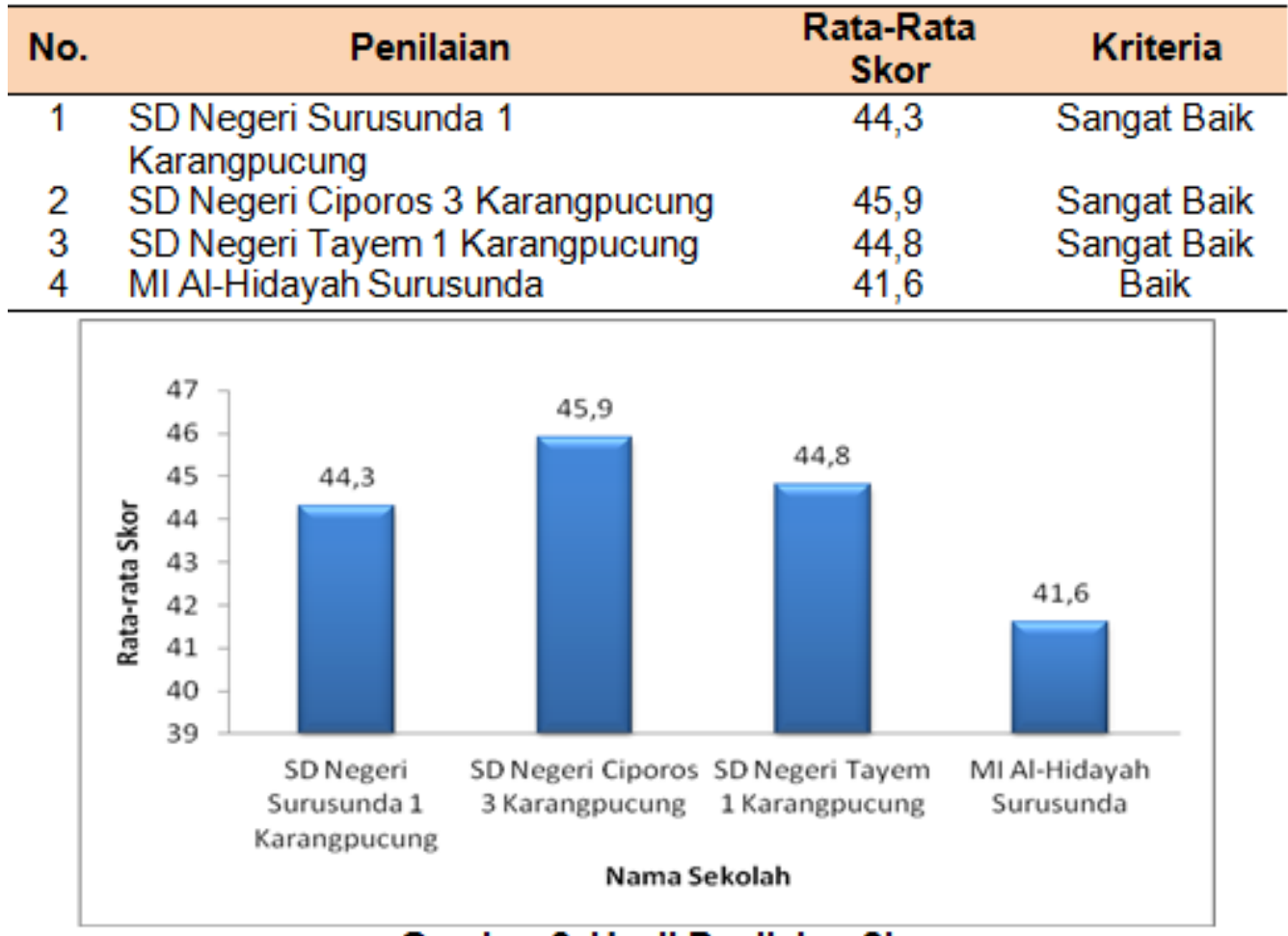

Gambar 2. Hasil Penilaian Siswa

Berdasarkan analisis hasil penilaian media pembelajaran dalam penelitian ini, maka dapat disimpulkan bahwa kualitas media video animasi IPA SD berbasis literasi 
sains berada pada kategori "Sangat Baik" dan pengguna media tidak mengalami kesulitan saat menggunakannya menurut penilaian berbagai ahli (media, bahasa, dan materi), guru dan siswa Kelas IV. Video animasi yang telah selesai dikembangkan, dapat menjadi alternatif media dalam peningkatan motivasi belajar siswa khususnya pada tema Selalu Berhemat Energi sehingga siswa lebih merasa tertarik dalam mempelajarinya. Hal ini sejalan dengan pendapat yang dikemukakan oleh Setiawan (2014:110) yang menyatakan bahwa pemanfaatan animasi dalam media pembelajaran dapat memberikan pengalaman tampilan yang berbeda dengan mengubah konsep abstrak menjadi lebih konkrit dan sederhana, sehingga dapat mudah dipahami oleh siswa dan dapat mendorong motivasi belajar siswa.

Media video animasi yang telah dibuat juga mendukung peningkatan literasi sains, hal ini dikarenakan karakter materi pada tema Selalu Berhemat Energi berisi tentang pengetahuan konsep yang didalamnya terdapat materi sumber energi dan sumber daya alam, sehingga untuk meningkatkan literasi sains siswa, maka dilakukan dengan cara kegiatan membaca. Dengan menggunakan media video animasi berbasis literasi sains yang telah selesai dikembangkan, siswa diarahkan melalui kegiatan interaktif dengan cara membaca yang selanjutnya diajak untuk menganalisis pemanfaatan sumber daya alam tertentu. Alasan peneliti melibatkan kegiatan membaca di dalam media ini dikarenakan kegiatan membaca merupakan dasar dari sebuah literasi. Dengan kemampuan literasi siswa yang tinggi, maka dapat dipastikan siswa mampu menyelesaikan permasalahan yang dihadapi. Begitupun sebaliknya apabila siswa tidak lancar membaca, maka kemampuan literasi siswa tersebut juga rendah sehingga kurang mampu beradaptasi dengan permasalahan yang dihadapinya. Hal ini sesuai dengan pendapat Nursholihat dkk (2017:712) yang menyebutkan bahwa contoh usaha dalam meningkatkan kemampuan literasi sains salah satunya adalah menjadikan siswa terbiasa untuk membaca, sehingga perlu disusun dan dikembangkan media/ kegiatan membuat siswa tertarik dan gemar untuk membaca.

Selain itu, di dalam media video animasi berbasis literasi sains yang telah dibuat juga terdapat kegiatan interaktif yang mengarahkan siswa untuk mampu dalam mencari jawaban penyelesaian dengan cara menjelaskan fenomena ilmiah yang terjadi dari bukti atau fakta yang diperoleh. Sehingga siswa dapat mengidentifikasi karakteristik tentang sumber energi, siswa mempunyai kesadaran bagaimana energi dan teknologi mampu membantu menangani krisis energi yang telah terjadi melalui energi alternatif, serta menjadikan siswa memiliki kepedulian terhadap lingkungan yang ada disekitar dalam kehidupan sehari-hari yang terkait dengan krisis energi dengan cara menghemat energi dan memanfaatkan energi alternatif sebaik mungkin. Hal ini juga sesuai dengan pendapat Bang (2018) yang menjelaskan bahwa literasi sains dapat mengembangkan serangkaian kemampuan siswa dalam menggunakan dan memahami pengetahuan ilmiah yang dimiliki sehingga mempunyai kesadaran dan kemauan peduli terhadap lingkungannya. Di sisi lain, dengan penggunaan media berbasis literasi sains, akan mendukung peningkatan komponen abad 21 yang meliputi beberapa kemampuan (berpikir kritis dan kreatif, berpendapat, dan berkerjasama) sehingga siswa memiliki kepedulian terhadap lingkungan yang ada disekitar dalam kehidupan sehari-hari. Hal ini juga diperkuat dengan pendapat Astuti, dkk (2017: 263) yang menyatakan bahwa penguasaan literasi sains dalam diri siswa sangatlah penting terutama dalam memahami aspek lingkungan, sosial, ekonomi, kesehatan dan lainnya agar mampu beradaptasi dengan perkembangan teknologi dan arus komunikasi yang semakin pesat dan cepat.

Selain itu, rendahnya kesadaran masyarakat terhadap program "Gerakan Hemat Energi" yang dicetuskan oleh pemerintah bisa berakibat fatal bagi kerusakan lingkungan. Bercermin terhadap hal tersebut, penting untuk siswa mengkaji, menyadari dan memahami tentang pentingnya program hemat energi. Sehingga dengan adanya 
urgensi tersebut, maka dalam penelitian ini tema pembelajaran yang dipilih adalah tema "Selalu Berhemat Energi" untuk siswa kelas IV SD dengan harapan setelah dilakukan pembelajaran berbasis literasi sains, siswa dapat memberi kontribusi pada lingkungan sosial terkait pentingnya hemat energi.

\section{SIMPULAN}

Berdasarkan hasil riset dan pengembangan dalam penelitian ini, diperoleh simpulan meliputi: (1) Media video animasi IPA SD berbasis literasi sains yang dihasilkan merupakan media pembelajaran IPA untuk kelas IV SD pada kurikulum 2013 dengan tema "Selalu Berhemat Energi", (2) Kualitas media video animasi IPA SD berbasis literasi sains berada pada kategori "Sangat Baik" dan pengguna media tidak mengalami kesulitan saat menggunakannya menurut penilaian beberapa ahli (media, bahasa, dan materi), guru dan siswa Kelas IV. Berdasarkan simpulan dan hasil wawancara terhadap guru sebagai pengguna media pembelajaran yang telah dikembangkan oleh peneliti, maka peneliti memiliki saran diantaranya: (1) perlu diadakannya penelitian lebih lanjut tentang keefektifan penggunaan media video animasi IPA SD berbasis literasi sains pada tema Selalu Berhemat Energi dalam proses pembelajaran, (2) perlu dilakukannya pengembangan media video animasi berbasis literasi sains pada mata pelajaran yang lain dan di tingkat kelas yang lain, (3) perlu dilaksanakannya pelatihan dan sosialisasi kepada guru-guru SD dalam pembuatan media pembelajaran menggunakan software atau aplikasi pembuat media yang mudah digunakan. Implikasi penelitian ini adalah menjadi alternatif media pembelajaran dalam meningkatkan literasi sains siswa melalui peningkatan cara berpikir kritis dan kreatif serta meningkatkan minat membaca materi pelajaran IPA dan yang terpenting didalam materi tersebut terdapat wacana "Hemat Energi".

\section{DAFTAR PUSTAKA}

Allison, Elizabeth; Goldston, M Jenice. (2018). Modern Scientific Literacy: A Case Study of Multiliteracies and Scientific Practices in a Fifth Grade Classroom. Journal of Science Education and Technology; New York Vol. 27, Iss. 3, (Jun 2018): 270-283.

Astuti, dkk. (2017). Pembelajaran Berbasis Masalah untuk Meningkatkan Literasi Sains pada Materi Hubungan Makanan dengan Kesehatan. Jurnal Pena IImiah: Vol. 2, No 1, Agustus 2017, Hal 261-270. e-ISSN 2540-9174.

Azhar, Arsyad. (2016). Media Pembelajaran. Depok: PT Rajagrafindo Persada.

Bang, Lars. (2018). In the maw of the Ouroboros: an analysis of scientific literacy and democracy. Scholarly journals: Cultural Studies of Science Education; Dordrecht Vol. 13, Iss. 3, (Sep 2018): 807-822.

Borg, W.R. dan Gall, M.D. (20030. Educational Research: An Introduction, Fifthy Edition. New York: Longman.

Fahmi, S dan Soffi W.P. (2017). Pengembangan Media Belajar untuk Mata Kuliah Logika Matematika dan Himpunan di Program Studi Pendidikan Matematika Universitas Ahmad Dahlan. AdMathEdu, Vol. 7, No. 2, Desember 2017, Hal 176196. ISSN: 2088-687X.

Irfandi. (2015). Pengembangan model pelatihan Sepak Bola dan Bola Voli. Yogyakarta: CV Budi Utama.

Kemdikbud. (2017). Materi Pendukung Literasi Sains Gerakan Literasi Nasional. Jakarta: Tim GLN Kemendikbud.

Munir. (2015). Multimedia Konsep \& Aplikasi dalam Pendidikan. Bandung: Penerbit Alfabeta.

Nursholihat dkk. (2017). Peranan Media Komik Terhadap Literasi Sains Siswa SD Kelas V pada Materi Daur Air (Penelitian Pre-Experimental Terhadap Siswa 
Kelas V SD Kecamatan Paseh Kabupaten Sumedang). Jurnal Pena IImiah: Vol. 2, No 1, Agustus 2017, Hal 711-720. e-ISSN 2540-9174.

Rafidah, Nurlina. (2017). Pengembangan Pocketbook Bermuatan Nature Of Science untuk Meningkatkan Literasi Sains Siswa SMP. S2 skripsi, FMIPA UNY.

Rakhmawan, Aditya dkk. (2015). Perancangan Pembelajaran Literasi Sains Berbasis Inkuiri pada Kegiatan Laboratorium. Jurnal Penelitian dan Pembelajaran IPA (JPPI), Vol. 1, No. 1, November 2015, Hal. 143-152. e-ISSN 2477-2038.

Riwanto, Mawan Akhir. (2018). Pengembangan Media Pembelajaran IPA Interaktif Berbasis Keterampilan Proses Sains untuk Kelas Atas Sekolah Dasar. Jurnal PANCAR, Vol. 2, No. 2, November 2018, Hal. 12-15.e-ISSN: 2550-0619.

Samatowa, Usman. (2016). Pembelajaran IPA di Sekolah Dasar. Jakarta: PT Indeks.

Setiawan, Andhika Budi. 2014. Pengaruh Penggunaan Media Animasi Terhadap Hasil Belajar Rencana Anggaran Biaya di SMK Negeri 3 Yogyakarta. S1 skripsi, FTEKNIK UNY.

Sulistyaningsih, Indah. (2015). Hubungan Minat Belajar dan Motivasi Belajar terhadap Prestasi Belajar IPA Siswa Kelas IVA di Salah Satu Sekolah Dasar Tahun Ajaran 2015/2016. Klaten: Universitas Sanata Dharma. https://repository.usd.ac.id/3370/

Susanto, Ahmad. (2016). Teori Belajar dan Pembelajaran di Sekolah Dasar. Jakarta: Kencana Prenada Media Group. 